Meta

Journal des traducteurs

Translators' Journal

\title{
Foreword
}

\section{Richard Kittredge}

Volume 26, numéro 1, mars 1981

L'informatique au service de la traduction

Machine Aids to Translation

URI : https://id.erudit.org/iderudit/003319ar

DOI : https://doi.org/10.7202/003319ar

Aller au sommaire du numéro

Éditeur(s)

Les Presses de l'Université de Montréal

ISSN

0026-0452 (imprimé)

1492-1421 (numérique)

Découvrir la revue

Citer ce document

Kittredge, R. (1981). Foreword. Meta, 26(1), 5-7.

https://doi.org/10.7202/003319ar

Ce document est protégé par la loi sur le droit d'auteur. L'utilisation des services d'Érudit (y compris la reproduction) est assujettie à sa politique d'utilisation que vous pouvez consulter en ligne.

https://apropos.erudit.org/fr/usagers/politique-dutilisation/
Cet article est diffusé et préservé par Érudit.

Érudit est un consortium interuniversitaire sans but lucratif composé de l’Université de Montréal, l'Université Laval et l'Université du Québec à Montréal. Il a pour mission la promotion et la valorisation de la recherche. https://www.erudit.org/fr/ 


\section{Foreword}

Computer aids to translation, of one kind or another, have been available now for more than 25 years. At the time the first primitive machine translation (MT) systems were demonstrated in 1954, translating Russian scientific articles into atrociously garbled English, the air was full of optimism that within a few years, given a bit more linguistic knowledge and larger machines, human translators could all turn to literature, leaving the machines to grind out the more mundane translations of parliamentary proceedings, training manuals and economic reports.

Translators themselves may have been somewhat skeptical, but the linguists and computing specialists were not to be deterred. Only in the late 1960 's did MT specialists fully realize that understanding and modelling the translation process is one of the major challenges of twentieth-century science, as elusive as the proverbial cure for the common cold. Despite the recent efforts of researchers in artificial intelligence, there has been only limited progress in endowing machines with the background knowledge required for understanding and translating typical texts. The few cases where reliable MT appears feasible today are limited to very stereotyped technical domains, where word-sense and text structure are not subject to serious variation. Since no all-purpose translation device appears to be on the horizon, it is safe to assume that ten or even twenty years from now, humans will still be bearing the brunt of the translation load.

Now that the limits of possible machine translation are becoming clearer, we are entering a period of intense development of computer aids designed to make the best and most efficient use of human and mechanical capabilities. The wide range of proposed and existing systems can be divided into two main categories, those for humain-aided machine translation (HAMT) and those for machine-aided human translation (MAHT). The first category can be subdivided according to the type of human intervention in the mechanized translation process. In the HAMT of very restricted sublanguages such as weather reports it is possible to design systems which translate flawlessly the sentences which are "accepted" by the grammar, leaving only "unusual" sentences (those outside the analysis capabilities of the system) for the human. This possibility does not exist for most varieties of language. A typical translation program will mistranslate (in a way undetectable by the machine) a certain percentage of the sentences that the grammar can recognize. Most MT systems must therefore be post-edited by a human revisor. Human intervention may also include pre-edition to provide supplementary information in a text or regularize unusual or difficult sections into machine-recognizable form. Another possibility is interactive guidance, occurring when a human operator replies to a request by the machine to provide further information or make a choice among several possibilities before returning the control to the machine for further processing. 
Computer aids in the second category may include a wide variety of systems, some of which are not designed with only the translator in mind. These may include word processors, text editors, terminology data banks of various kinds, data banks of translated texts, concordance generators, typesetting systems, etc. In fact, the conception and development of tailormade translation support systems made up of several modules which put a range of tools at the translator's disposal is now in the realm of reality. The only impediments to their use are the cost of establishing and maintaining the computing software and data banks.

The organization of this special issue of META reflects the division between HAMT and MAHT systems. In the lead article, B. Vauquois, director of Grenoble's Groupe d'études pour la traduction automatique, presents some of the basic definitions, problems and perspectives for HAMT. The article by Alan Melby represents the work at Brigham Young University on interactive guidance in a multi-purpose HAMT system. The next two papers represent fullscale systems which have grown out of the research and development work at the TAUM project of the University of Montreal. The METEO system, used in the daily translation of Canada's weather bulletins, is described by Chandioux and Guéraud from the point of view of operational efficiency and user (translator) comfort. In the paper on TAUM's prototype AVIATION system, (Chevalier, Isabelle, Labelle and Lainé) the accent is on the way in which the linguists and translators encode their specialized knowledge in the system's rules during the actual building of such a system.

The second group of articles deals with various aspects of automated human translation in which the function of machines is to increase the efficiency and access to knowledge of the translation professional. First W. Schwab surveys a variety of translation aids now in use as well as several perspectives for future development. Next, A. Andreyewsky outlines some theoretical considerations for comparing robotic and non-robotic translation. The remaining papers deal with the existing and proposed machine aids for specific translation agencies. H. Brinkmann gives the viewpoint of a large commercial organization while J. Goetschalckx reports on a large governmental agency. The article by G. Brace provides a case history showing how computerized data banks were used in solving a difficult translation problem. Finally, F. Krollmann examines the achievements and perspectives of MAHT within one of the world's largest governmental agencies.

One of the points of common agreement of all these authors is the urgent need for translation specialists to become more actively involved in the design of new automated translation systems. Their support is needed not only in formulating the specific translation rules of HAMT systems, but also in identifying possible areas of application for machine aids (HAMT or MAHT) and in passing judgement on the usefulness and comfort of these aids. It should not be forgotten that one of the world's few functionning translation systems (METEO) was conceived when a specific human translator appealed to a university research group to provide some relief for one of the more repetitious and unre- 
warding kinds of translation activity. Without his identifying the need and taking the initiative to enter an unfamiliar environment, one of the real MT achievements of the last decade would not have taken place.

RICHARD KITTREDGE 